\title{
Controlling Groundwater Exploitation Through Economic Instruments: Current Practices, Challenges and Innovative Approaches
}

\author{
Marielle Montginoul, Jean-Daniel Rinaudo, Nicholas Brozović, \\ and Guillermo Donoso
}

\begin{abstract}
Groundwater can be considered as a common-pool resource, is often overexploited and, as a result, there are growing management pressures. This chapter starts with a broad presentation of the range of economic instruments that can be used for groundwater management, considering current practices and innovative approaches inspired from the literature on Common Pool Resources management. It then goes on with a detailed presentation of groundwater allocation policies implemented in France, the High Plains aquifer in the USA, and Chile. The chapter concludes with a discussion of social and political difficulties associated with implementing economic instruments for groundwater management.
\end{abstract}

\subsection{Introduction}

As detailed in Chap. 2 and elsewhere in this book, groundwater abstraction has increased considerably over the last few decades for both agricultural and urban uses. In many parts of the world, government agencies have not paid sufficient

\footnotetext{
M. Montginoul $(\bowtie)$

Irstea - UMR G-Eau, Montpellier, France

e-mail: marielle.montginoul@irstea.fr
}

J.-D. Rinaudo $(\bowtie)$

Water Department, BRGM, French Geological Survey, Montpellier, France

e-mail: Jd.rinaudo@brgm.fr

N. Brozović

Robert B. Daugherty Water for Food Institute, University of Nebraska, Lincoln, NE, USA

G. Donoso

Department of Agricultural Economics, Pontificia Universidad Católica de Chile, Santiago, Chile 
attention to this 'silent revolution'. Groundwater development has thus taken place in an institutional setting that placed no or few limits on groundwater use. Tens of thousands of wells and boreholes were constructed by small private agricultural or urban economic actors, leading to overdraft and associated environmental impacts (e.g. sea water intrusion, declining water tables, impacts on dependent ecosystems). In countries where groundwater has long been considered as an open access good, the establishment of new rules for governing access to groundwater and its use is increasingly perceived as necessary. This calls for the design of innovative institutional frameworks, involving the redistribution of responsibilities between the State and user communities, and an increased use of economic instruments providing incentives and theoretically leading to higher water use efficiency.

In practice, the shift from an open access to a regulated use regime has been implemented with three distinct policy approaches, depending on the local or national economic, legal and social context. The first approach (command and control) consists of establishing or reinforcing direct administrative regulation, with systematic registration of abstraction points, the issuance of pumping permits, and the award and enforcement of individual volumetric quotas. This approach is illustrated by the case of France, described in detail in Sect. 22.3 of this chapter. The second approach is founded on private appropriation of the resource, and involves the allocation of water use rights (the nature of which can differ significantly from one country to another) which can be traded amongst users, under supervision of a State agency. Such groundwater markets exist in several countries including the USA, Chile (see Sects. 22.4 and 22.5 of this chapter), Australia (Skurray et al. 2012), China (Zhang et al. 2008) and Spain (Garrido et al. 2012), among others. The third approach is founded on the decentralization of water allocation policies and the devolution of a number of State responsibilities to Water Users Communities or Associations. This model has been implemented with varying level of success in Spain or Mexico (Mukherji and Shah 2005), and underlies the recent evolution of groundwater policy in France.

In each of these three policy approaches, water managers are dealing with similar issues, including: the definition of the nature of water use rights; the control of free riding behaviors and the access to information on abstraction points and actual water withdrawals. In the following sections, we illustrate how these issues have been addressed in three different contexts in France, the USA and Chile. We also describe existing economic instruments and innovative ones that could be implemented to control access to and the use of groundwater.

The chapter is organized as follows. It starts with a broad presentation of the range of economic instruments that can be used for groundwater management, considering current practices and innovative approaches inspired from the literature on Common Pool Resources management (Sect. 22.2). The chapter then goes on with a detailed presentation of groundwater allocation policies implemented in France (Sect. 22.3), the High Plains Aquifer in the USA (Sect. 22.4), and Chile (Sect. 22.5). The chapter ends with a discussion of social and political difficulties associated with implementing economic instruments for groundwater management. 


\subsection{Economic Instruments for Groundwater Management: Approaches and Challenges}

Since the 1980s, there has been a growing recognition that economic instruments should be used to regulate the access to and the use of water resources. However, a review of existing practices shows that situations resembling Hardin's tragedy of the commons still prevail in most places around the world (see Chap. 23). This situation reflects the significant difficulties encountered by policy makers and managers to deploy economic instruments, in particular due to the lack of information on water users, abstraction points and water withdrawals, as well as the difficulties in enforcing allocation rules and instruments. This first part of the chapter proposes to look at existing and innovative tools that are, or could be, deployed to ensure sustainable management of overexploited aquifers.

\subsubsection{The Information Problem}

One of the main challenges faced by water managers attempting to control groundwater use is the lack of information regarding the hydrology of the aquifer and the abstractions. More specifically, well developed and calibrated models are not usually available, which does not facilitate estimation of the stock and recharge levels. In Chile, for example, there is little to no knowledge of the aquifers south of Central Chile. Moreover, the number of abstraction points, their location, the average volume pumped and the period at which the pumping takes place are often unknown. Indeed, the control of groundwater - a three-dimensional system - is more complex than for surface systems (one-dimension). The existence of undeclared or illegal wells remains an issue even in developed countries, both in the urban and agricultural sectors. When abstraction points are known, meters are not always installed or they can be temporarily removed or tampered with. This is illustrated with several agricultural and urban case studies selected in southern Europe such as in Spain or in France (de Stefano and Lopez-Gunn 2012; Montginoul and Rinaudo 2011), and elsewhere in the world.

In such contexts, groundwater abstraction control policies have focused on circumventing the monitoring problem by using readily observable information that can be used as a proxy for groundwater abstraction. Four different levels of information can be targeted depending on the effort made.

- On the first level, the agency decides to rely on aggregate information which provides a proxy for the overall groundwater abstraction - for instance the measurement of groundwater table levels. A decline of water table (adjusted considering climatic conditions) indicates an increase of water abstraction and can trigger temporary bans on irrigation, for instance. Sophisticated groundwater models can also be used to assess total abstraction with better accuracy. 
- The second level consists of identifying and locating all abstraction points and users. This can be done in a deterministic way (through field surveys for instance) or based on self-declaration.

- This information can be improved (third level) by collecting technical information on the characteristics of the wells (pump capacity), on irrigated areas and type of crops grown by farmers and on the type of irrigation system used (drip or furrow irrigation). Rough estimates of individual abstraction can then be derived from this information.

- The fourth level of information is when water use is fully metered, the agency knowing who uses how much water in which place at different periods of the year.

\subsubsection{Current Policies}

Policies currently implemented by groundwater management agencies to reveal groundwater use information mostly rely on command and control mechanisms. The most frequently used approach relies on random control and penalties. Two main constraints usually limit the efficiency of this type of system: first, the agency often lacks the required human resources to inspect a significant proportion of users; second, fines imposed are kept low for political reasons. Overall, the risk of running an illegal well or under-declaring water abstraction is perceived as very limited by users who are facing little incentives to comply with the regulatory framework (cost of non-compliance is lower than cost of compliance). The efficiency of the inspection and sanction system can however be improved in several ways. The first one consists of increasing inspection probability or the fine for users who were caught in fraud. The second one could consist of providing incentives for all users getting involved in the monitoring of groundwater abstraction, in order to increase the probability of control. The cost of decentralized monitoring is expected to be lower, since agents possess information on the actions of other agents (areas and crops irrigated, irrigation practices and frequencies, etc.). The incentive to participate in a decentralized monitoring system can be provided by redistributing a share of the fine to the person who discovers the violator. This system has been used for centuries for regulating access to common pastures and forests in the Italian Alps (Casari and Plott 2003). It may however be strongly assimilated to denouncement and thus rejected in many cultural contexts.

The second policy approach, mainly used in the agricultural sector, consists of assessing individual water abstractions through indirect information, such as the observation of cropping patterns with satellite images (Castaño et al. 2010) or electricity bills (when wells are electric-powered). An illustration can be found in Mancha Oriental (Spain), where a groundwater user association (Junta Central de Regantes de la Mancha Oriental) uses satellite images to assess monthly groundwater use for each individual farmer. If the estimated water abstraction exceeds the quota allocated to the farmer $\left(4000 \mathrm{~m}^{3} / \mathrm{ha}\right)$, a field inspection is carried out and a fine is charged to the farmer in the case of non-compliance (Martin de Santa Olalla et al. 1999, 2003). 
Desprats et al. (2011) suggested that a similar approach could be used to identify unlicensed urban groundwater users. This would apply to low density urban areas where households use private wells for watering lawns and gardens and filling swimming pools. Their method consists of using high resolution aerial photographs to assess irrigated lawn areas and swimming pools and to compute the corresponding outdoor water use for each single family house. They then compare estimated outdoor water requirements with metered water bills to identify households using private wells. The method is applied to a southern France case study to detect undeclared domestic boreholes.

Another way to incentivise users to reveal more accurate information is the charging of a high flat rate when users refuse to declare information on abstraction. This is actually used by the Rhône Water Agency in France, which charges high irrigation water fees on a per hectare basis (crop differentiated) to farmers who refuse to meter water abstraction. However, in spite of the economic incentives, some farmers prefer paying high charges for preserving the information asymmetry, fearing that water fees may rise in the future once meters have been installed everywhere. This echoes the "ratchet principle" enunciated by Weitzman (1980): economic agents may refuse higher rewards for better current performance by fear of future assignment of more ambitious targets.

A fourth policy approach comprises linking groundwater management with other economic policies. In Europe for instance, the grant of subsidies under Common Agricultural Policies is conditioned by full compliance with environmental regulations (eco-conditionality). This compels farmers to declare their wells to the relevant authorities and to demonstrate that appropriate metering devices are installed. Similar constraints are imposed on farmers by supermarkets through the use of certification standards (e.g. Global Gap) which aim at providing consumers the security that the products they purchase have been produced in conformity with existing environmental regulations.

\subsubsection{Alternative Policy Options Based on Incentives}

Several other proposed instruments have been suggested in the Common Pool Resources literature to force users to reveal information on harvesting level. Although none of them have been applied to groundwater management, they can theoretically be considered as possible options worth being assessed in terms of efficiency, equity and acceptability.

One of these theoretical options involves combining an upfront payment with compliance rebate. The mechanism is inspired from the "guilty until proven innocent" principle enunciated by Swierzbinski (1994) in his work on pollution control. Applied to groundwater abstraction, it could work as follows. Every user is requested to declare what his groundwater abstraction is (self-reporting principle) and he pays an initial fee or tax that depends on what he reports. The agency in charge then conducts random inspections and quantifies actual water abstraction, based on costly audit. In the case of proven non-compliance, the user is punished with a dissuasive fine; if findings of the audit are consistent with the initial declaration, the user is rewarded with a rebate. Auditing probability is inversely 
correlated to the declared intensity of groundwater use (in $\mathrm{m}^{3}$ per hectare for instance). The relative values of the fine and of the rebate determine on which of the two mechanisms (sanction or reward) the incentive structure depends.

A variant of this instrument can be proposed if we assume that the audit cost can be lowered through active cooperation of the user (e.g. weekly on-line recording of water uses). In that case, voluntary agreements could be signed between users willing to be audited and the regulator. The main advantage of this system is that it shifts the burden of proof from the regulator to the user. This mechanism is similar to deposit-refund systems which have been advocated to control other environmental problems.

\subsubsection{Instruments for Groundwater Abstraction Control}

Based on Salzman's classification, five instruments can be used to control groundwater abstraction (Salzman 2005): (1) command and control; (2) penalty (including tax); (3) payment (including subsidies); (4) appropriation (tradable property rights); and (5) persuasion. Some of them are incentive-based instruments (2-3-4), others aim to manage groundwater abstraction through an administrative or concerted share of available water, or through influencing withdrawers taking into account psychological and social aspects. Although this chapter is primarily dedicated to economic instruments, these five instruments are presented here because they can be combined to increase the efficiency of incentive-based instruments or are in competition.

\subsubsection{Command and Control}

The command and control approach relies on the definition of restrictions of use that can take different forms depending of the level of available information. When abstraction points are known and water uses fully metered, a system of individual abstraction quotas can be implemented. Quotas can be adjusted every year to account for variability of groundwater recharge. Enforcement requires a system of control (meter reading) which can be costly. This allocation procedure is a source of economic inefficiency, quotas being frequently allocated based on historical records. More simple restriction approaches are used when information is lacking, such as a temporary ban on irrigation when groundwater levels fall below certain pre-specified threshold level. An intermediate approach lies in restricting the pumping capacity of users while granting pumping licenses. Water abstraction can also be controlled through rationing energy used for pumping, a current practice in several Indian States (Shah 2008). An alternative is non-tradable water rights (water use rights) that specify maximum allowable extraction water flows for each abstraction point. The advantage of this command and control instrument is that it allows the taking into account of geographical differences in water abstraction levels for the same aquifer. As with the quota system, non-tradable water rights require a costly system of control. Chile's 1951 Water Code (Ley 9909, 1951) employed this instrument. 


\subsubsection{Abstraction Tax Systems}

The tax approach assumes that consumption (households) or production decisions (farmers) can be influenced by the cost of water supply. The type of tax system that can be implemented again depends on the level of information available to the regulator.

If water abstraction is metered, an individual (Pigouvian) tax system can be used. The tax can also be levied on inputs used for pumping such as electricity. In both cases, the choice of an efficient tax level is not trivial, in particular where demand and available resource significantly fluctuate over time. If the tax level is set to ensure that no over-exploitation takes place in a normal climatic year, it will not allow meeting this objective in drought years, when farmer's willingness to pay for water is extremely high. If on the contrary, the tax level is set taking drought years into consideration, it will represent an unacceptable economic burden for farms during normal years. The choice of an efficient tax level is further complicated by conjunctive use of surface and groundwater, farmers' decisions to use one or the other resource being influenced by the relative level of taxes charged for the two different resources (Lenouvel and Montginoul 2010).

If abstraction points are unknown or if water use is unmetered, the regulator can charge all actors using groundwater with an ambient tax with level proportional to the aggregate over-exploitation level (Segerson 1988). The regulator can assess the aggregate abstraction level based on simple observation of groundwater level decline, or use more sophisticated groundwater models that account for climatic and other natural recharge conditions. Each user is then charged with the same tax level, irrespective of his or her actual groundwater use. To cope with the risk of excessive fines, Segerson also proposed to supplement ambient taxes with a lump sum subsidy which ensures that the correct group of users remain in production.

\subsubsection{Payment}

The payment approach assumes that water demand can be curved downwards by subsidies which reduce the profitability of activities using a lot of water. The instrument can be implemented even in the absence of accurate information on water use, since the payment is based on observable characteristics (crop choice or irrigation equipments) that are assumed to be strongly linked with groundwater use. This approach has been implemented in Europe where farmers agreeing to stop irrigation are granted significant subsidies during a 5-year period in order to reorganize their farm for rainfed crops. The payment can be offered on an individual basis or made dependent on collective change, for instance in terms of irrigation practices by all farmers in a specific groundwater recharge area. The payment is generally part of a contract signed between the regulator and one or several groundwater users (Salzman 2005). The main difficulty of such an instrument lies in its sustainability: funds must be provided and once subsidies are stopped, farmers may once again increase their water consumption to maintain their income. 


\subsubsection{Tradable Abstraction Water Rights}

Appropriation is a fourth approach. It assumes that the distribution of individual or collective property rights may support the development of rules and associated micro-institutions (Ménard 2003) to enforce those rights by local communities (in particular in the case of collective appropriation); the main assumption is that this local regulation will facilitate coordination between actors and reduce transaction costs. Appropriation through tradable water rights enables the development of water markets through which water can be reallocated among users, theoretically leading to improved water use efficiency. This policy approach is illustrated with the US High Plains case study below.

\subsubsection{Persuasion}

Persuasion is the fifth approach. It assumes that water use can be significantly reduced by providing users with information on the consequences of over-exploitation (in particular when irreversibility occurs with implication for future generations) and by increasing transparency on who uses what. This is supported by recent developments in psychological research dealing with common dilemmas, which highlight "that people are not just motivated by narrow (economic) selfinterest but that they also consider the broad implications of their decisions for others and for the natural environment" (Van Vugt 2009).

\subsection{From Command and Control to Self-Regulation: The Case of France}

The case of France is illustrative of a transition from command and control to a decentralized groundwater management policy, where economic incentives play a very limited role and appropriation is still resisted by policy makers and the society in general.

\subsubsection{Legal and Institutional Framework}

In France, as in many other EU countries, groundwater development has occurred in an institutional setting that imposed few if any limits on groundwater use. Until the 1992 water law, existing regulation mainly focused on surface waters and on objectives related to minimum in-stream flow and aquatic ecosystems protection. Few constraints were imposed on groundwater development until the 1990s. Wells were not always notified and authorized discharges were not complied with. A rapid development of agricultural groundwater use ensued. Since 2000, half of the total agricultural irrigated area in France depends on groundwater (Garin et al. 2013). In several parts of France, this has resulted in declining water tables, with significant impacts on dependent rivers and ecosystems. 
The situation started to evolve with the 1992 water law which strengthened the well licensing system and imposed the use of meters. The law also established the concept of "water scarcity zones"1 where local regulators could ban the construction of new wells and restrict pumping through allocating individual abstraction ceilings (in volume per year). This new regulatory framework was implemented in several groundwater basins (Fig. 22.1), the most well-known being the Beauce aquifer in central France.

Public water utilities were given priority over other uses in water allocation. Concerning agriculture, the allocation of individual volumes was made by governmental agencies, based on environmental impact considerations, after consultation with the Chamber of Agriculture. The State kept the sole responsibility for enforcing water allocation, although it lacked the human and financial resources to conduct the required controls. Conflict resolution relied fully on judicial procedures, but court cases were often abandoned and penalties charged to offenders were not dissuasive. Overall, this "command and control" institutional set-up established by the 1992 law did not succeed in averting over-exploitation. The frequency of water crises increased and temporary restrictions and even total irrigation bans were promulgated every year in many groundwater basins.

The regulatory framework was again reformed in 2006 with the promulgation of a new Law on Water and Aquatic Ecosystems. In aquifers considered at risk of over-exploitation, hydrogeological studies need to be conducted to assess the total maximum volume that can be abstracted (capping procedure). This volume (which can be much lower than current aggregate use) must then be shared among users. Urban water supply is still given priority. Concerning agricultural use, Groundwater User Associations ${ }^{2}$ (GWUAs) must be established locally to share the available amount of water among farmers (Fig. 22.1). GWUAs also have the option to raise water fees, and to implement new instruments to enforce allocation. This opens an interesting space for testing innovative instruments, inspired from theoretical research and from on-going experiences in other countries.

This brief historical description shows two main transformations underlying groundwater policy reform. First, the focus is shifted from command and control to a decentralized management approach. The State is progressively transferring responsibilities to farmers, through the establishment of micro-institutions which are "inserted between global rules that circumscribe the environmental context on the one hand, and agents, organizations and contractual agreements they are tied with on the other hand" (Ménard 2003). Such intermediary institutions adapt general institutional rules to effective local organizations and allow transaction costs to be reduced. As for groundwater, it is assumed that a locally-designed institution will be more efficient than the government at enforcing a groundwater quota system. The second transformation relates to allocation procedures. The

\footnotetext{
1 «Zones de Répartitions des Eaux» in French.

${ }^{2}$ Organisme Unique de Gestion Collective (OUGC) in French.
} 

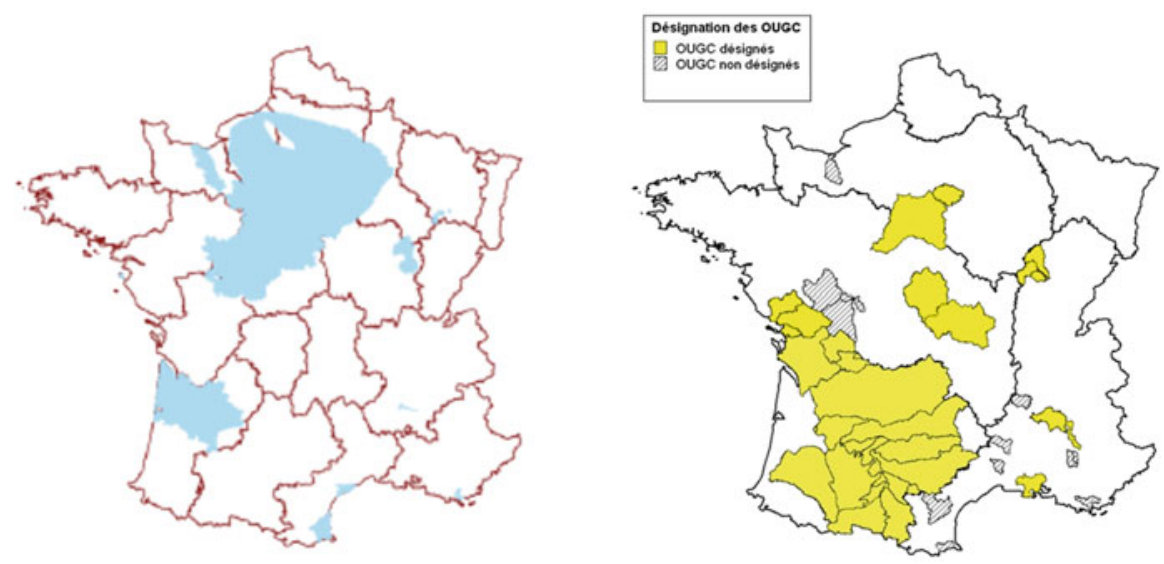

Fig. 22.1 Groundwater scarcity areas (left) and areas where Water Users associations have been established (surface and groundwater)

establishment of individual quotas can be considered as a first move towards an appropriation approach. In theory, quotas are very far from being property rights, since they can be reduced or even suppressed without any compensation. In practice, administrative pumping authorizations remain attached to the land in the case of land transactions, which implies that the land price reflects the value of the rent attached to the water quota. Appropriation is well underway, although this is not recognized officially.

\subsubsection{Economic Instruments in Place}

As shown in the previous section, groundwater allocation is mainly driven by command and control instruments, including temporary restrictions and individual quotas in "water scarcity zones". And since the 1964 Water Law an abstraction tax is also charged by Water Agencies. The main objective of this tax is not to signal scarcity, but to raise revenues that can be used to subsidize water related projects. The tax level is regulated by the National Parliament which sets a maximum level for different uses (see Table 22.1). Tax levels are far too low to provide any real incentive to reduce groundwater extraction. For instance, the average rate charged for irrigation (traditional gravity systems excluded) is only $3.6 €$ per thousand cubic meters. Although it is doubled in "water scarcity zones", it does not signal water scarcity. Moreover, the abstraction fee is not recovered from small water users (less than $10,000 \mathrm{~m}^{3}$ per year). Small economic enterprises and domestic users who directly pump groundwater are therefore exempted from the tax. 
Table 22.1 Maximum tax level $\left(€ / \mathrm{m}^{3}\right)$ on water resource extraction (applied from January 2013)

\begin{tabular}{l|l|l}
\hline Uses & $\begin{array}{l}\text { Normal rate }(€ / \\
\left.\mathrm{m}^{3}\right)\end{array}$ & $\begin{array}{l}\text { Water scarcity zone } \\
\left(€ / \mathrm{m}^{3}\right)\end{array}$ \\
\hline Irrigation (except by gravitary) & 0.036 & 0.072 \\
\hline Gravitary irrigation & 0.005 & 0.01 \\
\hline Potable use & 0.072 & 0.144 \\
\hline $\begin{array}{l}\text { Industrial cooling (with more than 99\% of water } \\
\text { restitution) }\end{array}$ & 0.005 & 0.01 \\
\hline Canal alimentation & 0.0003 & 0.003 \\
\hline Other economic uses & 0.054 & 0.108 \\
\hline
\end{tabular}

Source: Code de l'Environnement, articles L213-14-1 et L213-10-9

\subsubsection{Issues and Problems}

The main problems and policy issues in current groundwater policies are now covered in this subsection. The first problem relates to law enforcement. Since 1997 all wells and borewells should be declared and equipped with meters. There are however still a number of places where this does not happen. Field investigations conducted by the authors in the Roussillon plain, Southern France, showed that only $1 \%$ of domestic boreholes and 40-63\% of agricultural boreholes have been declared (Montginoul and Rinaudo 2009; Desprats et al. 2011). In that case study area, the Chamber of Agriculture collects the information on wells from farmers but they withhold it fearing that it can be used against them in the future. And when wells are declared, farmers prefer continuing to pay the flat rate abstraction fee to the Water Agency rather than declaring the volumes they actually used, even though this would clearly be favorable to them. The situation persists because sanctions are not dissuasive, the probability of control is too low, offenders are not systematically prosecuted (many cases are abandoned in overburdened courts), and due to a general lack of political will.

The second problem relates to water allocation efficiency. Water quotas have generally been granted based on records of historical use. In certain areas, like in the Tarn et Garonne county, the "use it or lose it" rule that should theoretically prevail in France, where water is considered as a public trust, is not applied. This results in situations where farmers may keep control over water quotas which they do not use, at the expense of other farmers who are queuing-up to obtain a quota from the government agency in charge. The corollary is a progressive feeling of private appropriation of water by farmers (and other users) who have been benefiting from a quota for years. The value of land reflects the existence and the magnitude of the attached water quotas, meaning that the water rent is appropriated by the land owner. This trend reflects current administrative practices which are in contradiction with the foundations of the 1992 and the 2006 water laws, both stating that water is a Nation's common heritage.

The third problem is that of perceived (un)fairness of water allocation. Many of the farmers in various French basins contest current water allocation which they find unfair and not equitable. They particularly contest the priority given to urban areas 
first before environment and agriculture. Another issue of controversy is around the rules for sharing water among farmers. The grandfathering principle, advocated by those benefiting from a quota based on historical use, is contested by other users who would like to enter the groundwater economy. This is nicely shown by a survey on water allocation rules conducted in five French regions, where the diversity of positions defended by farmers on this issue can only be understood by analyzing self-interest economic motivations jointly with ethical beliefs and values (Chap. 11).

Last but not least, groundwater policy reform is somehow blocked by lobbying efforts made by agricultural stakeholders who try to obtain public subsidies to construct small reservoirs as a substitute for groundwater use.

\subsubsection{Options for Future Policy}

In France, policy makers are at a crossroads where three different approaches can be chosen to develop national groundwater regulation.

\section{- Pursuing decentralization}

The first policy approach consists of pursuing decentralization. It requires strengthening the legal status and the internal capacity of newly established GWUAs to setup and implement their own groundwater regulation. GWUAs would become more involved in conflict resolution, for instance through establishing a "groundwater tribunal" composed of elected farmers and government representatives and who would arbitrate conflicts and charge penalties on offending farmers. GWUAs would also need to design their own rules for allocating water among their members and facilitating (monetary or non-monetary) exchanges between their members, in search of flexibility and efficiency. Contract-based instruments may play a significant role in decentralized management. For instance, Figureau et al. (2015) have proposed a "pooling agreement" through which farmers would agree to mutualize their quotas, in search of greater flexibility. The contract is favorable to the agents as a team relative to the standard penalty system provided that the team does not exceed the targeted abstraction level, but unfavorable to the team if the target is exceeded. Participating in a group remains a voluntary decision and not all farmers are expected to engage in these types of agreements.

As shown by the abundant literature on common pool resources, the main advantage of decentralized groundwater management is that rules are likely to be adapted to the local context. In France, this would respond to a real demand from farmers, as shown by the above-mentioned recent farm survey (Chap. 11) in five very different French counties. It highlights that farmers have highly diverging views concerning which criteria should be used to share water and how frequently allocation should be revised. For instance, while fruit farmers in the west (Tarn et Garonne) are asking for 15-20 years of water use concessions, cereal and vegetable growers in the north (Aisne county) would like allocation to be revised every year. 


\section{- Strengthening administrative regulation}

The second approach involves strengthening direct administrative regulation, with systematic registration of abstraction points, the issuance of pumping permits, and the awarding and enforcement of individual volumetric quotas. Water quotas are granted for a duration compatible with irrigation investments (e.g. 15 years) and have the status of concessions as practised under the Spanish law. Beneficiaries of concessions must report detailed information to government agencies on where they use water and for which crop, using an internetbased geographic information system similar to what is currently required by the Common Agriculture Policy subsidies. Automated reading meters such as those used in the drinking water sector help solve the information problem. The enforcement problem is dealt with by the use of sophisticated remote-sensing technology coupled to field inspections. A fine, proportional to the excess water used, is applied in case of non-compliance. One of the drawbacks of this policy approach is the lack of flexibility: newcomers (young farmers) are unable to obtain a concession until another farmer relinquishes a license - possibly providing incentives for farmers to drill illegal wells or to engage in informal water trading. Water use efficiency is obviously another issue. And enforcement is likely to be problematic in a context where scarce financial resources are allocated to government agencies in charge of water and environmental policies.

- Using incentive-based economic instruments

The third model gives more importance to incentive-based economic instruments, which can be implemented by the State or within GWUAs. Several tools have been proposed and tested experimentally by French economists.

- The establishment of markets where water quotas could be traded has been advocated since the early 2000s (Strosser and Montginoul 2001) and more recently evaluated through consultation with farmers in different regions (Rinaudo et al. 2012, 2014). Creating markets would not require many institutional changes if water abstraction is properly capped (as suggested in the second approach) and they could even operate without privatizing water, based on a concession system as currently is happening in Spain.

- Lenouvel et al. (2011) tested an instrument combining an ambient tax with a contract. The ambient tax is indexed according to groundwater level, and it is charged to all farmers of the area. Farmers are offered the option to sign a contract with the GW basin agency in which they commit to provide true information to the agency concerning the location of their wells, irrigated fields, and volume pumped, and to facilitate the control of this information. These farmers are exempt from the ambient tax. The information they provide is verified using remote sensing and field inspections.

- Figureau et al. (2015) have proposed combining payments and fines. Farmers exceeding their quota pay an increasing block fine for the extra volume pumped. The sum of the fines collected is then shared between those farmers who use less than their entitlement, the received amount being proportional to the water saving effort made. This instrument, which is expected to meet water and budget balance simultaneously, is currently being tested through experiments with farmers. 


\subsubsection{Social Expectations}

Considering a 20-year time horizon, the three paths represent alternative feasible options, provided significant evolution of the legal framework occurs. However, future evolution may be strongly determined by social expectations. A series of workshops conducted with 80 farmers and 44 institutional stakeholders suggest that there is a strong social preference for decentralized solutions and cooperative arrangements, while economic instruments like taxes and market are strongly rejected mainly based on ethical considerations (Figureau et al. 2015; Rinaudo et al. 2014). Similar conclusions were reached by Montginoul and Rinaudo (2009) from a survey conducted in southern France by Rinaudo et al. (2014). Overall, water remains perceived as a free access good and implementing economic instruments is considered to be a drastic shift in paradigm. Transition towards a mature water economy will necessarily take place as climate changes and demand increases, but this will take time.

\subsection{From Command and Control to Markets: Examples from the High Plains Aquifer, USA}

\subsubsection{Background on Groundwater Management in the United States}

In the United States, the connections between groundwater pumping, local economies, and freshwater ecosystems that are fed by groundwater have been the subject of extended study and litigation over the last decade (e.g. Hathaway 2011; Van Kirk and Naman 2008; Scanlon et al. 2012; Gleeson and Cardiff 2013; Steward et al. 2013). Importantly, there is no national water policy related to groundwater use in the United States (see also Chaps. 6, 7, and 8). Instead, groundwater regulations are often set and implemented locally and not at a state or federal level. Changes in regulations are primarily driven by legal impositions on local groundwater management districts, or by a desire to preserve a rural way of life for future generations.

Common concerns about the sustainability of groundwater use may be divided into three broad categories: concerns over aquifer depletion (Konikow 2013; Laukaitis 2013; Steward et al. 2013; Terrell et al. 2002; Wines 2013), concerns over damages to transboundary surface water resources resulting from surface water-groundwater interaction (Kuwayama and Brozović 2013; McCarl et al. 1999), and concerns over damages to groundwater-dependent ecosystems and endangered species from surface water-groundwater interaction (Van Kirk and Naman 2008).

As a result, there is a very fine-scale heterogeneity of regulations related to groundwater use. Whereas large portions of the United States do not have any meaningfully binding restrictions on groundwater use, there is also a growing 
number of areas where quantification, monitoring, and enforcement of pumping rights have been implemented. Moreover, there are also examples where markets in groundwater pumping rights are emerging. Finally, in at least one case, voluntary changes in water rights that allow binding reductions in agricultural groundwater pumping have occurred (Kuwayama and Brozović 2013; NE DNR and MRNRD 2010; NE DNR and TBNRD 2012; NE DNR and URNRD 2010; Thompson et al. 2009). In the remainder of the section, we will focus on describing some of these recent, innovative approaches to groundwater management.

\subsubsection{Introduction to the High Plains Aquifer Region}

The High Plains aquifer system is one of the largest groundwater aquifers in the world (McGuire et al. 2012; Fig. 22.2). It supports endangered species, ecosystems, and rural economies in an area covering multiple states (Gutentag et al. 1984; Rosenberg et al. 1999; Dennehy et al. 2002) and a variety of hydrologic and climatic settings. As a result, both the management concerns and institutional responses to these concerns vary enormously across the region.

Each state above the High Plains aquifer has its own groundwater administration areas. These areas are called Natural Resources Districts (NRDs) in Nebraska, Groundwater Management Districts (GMDs) in Kansas, and Groundwater Conservation Districts (GCDs) in Texas. All three categories of groundwater-related conflict discussed in the previous section are observed in the High Plains (Fig. 22.2). First, the major concern over groundwater may be related to declining well yields as pumping reduces saturated thicknesses (e.g. Northwest Kansas GMD\#4, North Plains GCD). Second, stream depletion related to groundwater pumping may lead to conflict between groundwater users and downstream surface water users (e.g. the Upper and Middle Republican NRDs, Big Bend GMD\#5). Finally, stream depletion may negatively impact endangered species and instream habitat (e.g. the Twin and Central Platte NRDs).

Effective groundwater management requires monitoring and enforcement of groundwater use. In the High Plains region, a large portion of the states of Kansas and Nebraska requires that all irrigation wells are metered and pumping reported annually. Meters are less common in Texas, but some groundwater management districts such as the North Plains Groundwater Conservation District are now phasing-in meter installation.

As noted above, monitoring of groundwater use is only meaningful to resource management to the extent that there is enforcement when violations occur. Where reporting of metering data is voluntary and without sanction, there is little incentive to provide timely or accurate readings. Conversely, in some groundwater management districts, paid district employees do the meter reading, with fines for broken meters and severe penalties for violators. For example, in 2010, the Upper Republican Natural Resources District in Nebraska revoked groundwater pumping rights, estimated to be worth in excess of $\$ 3$ million, for several groundwater users who 


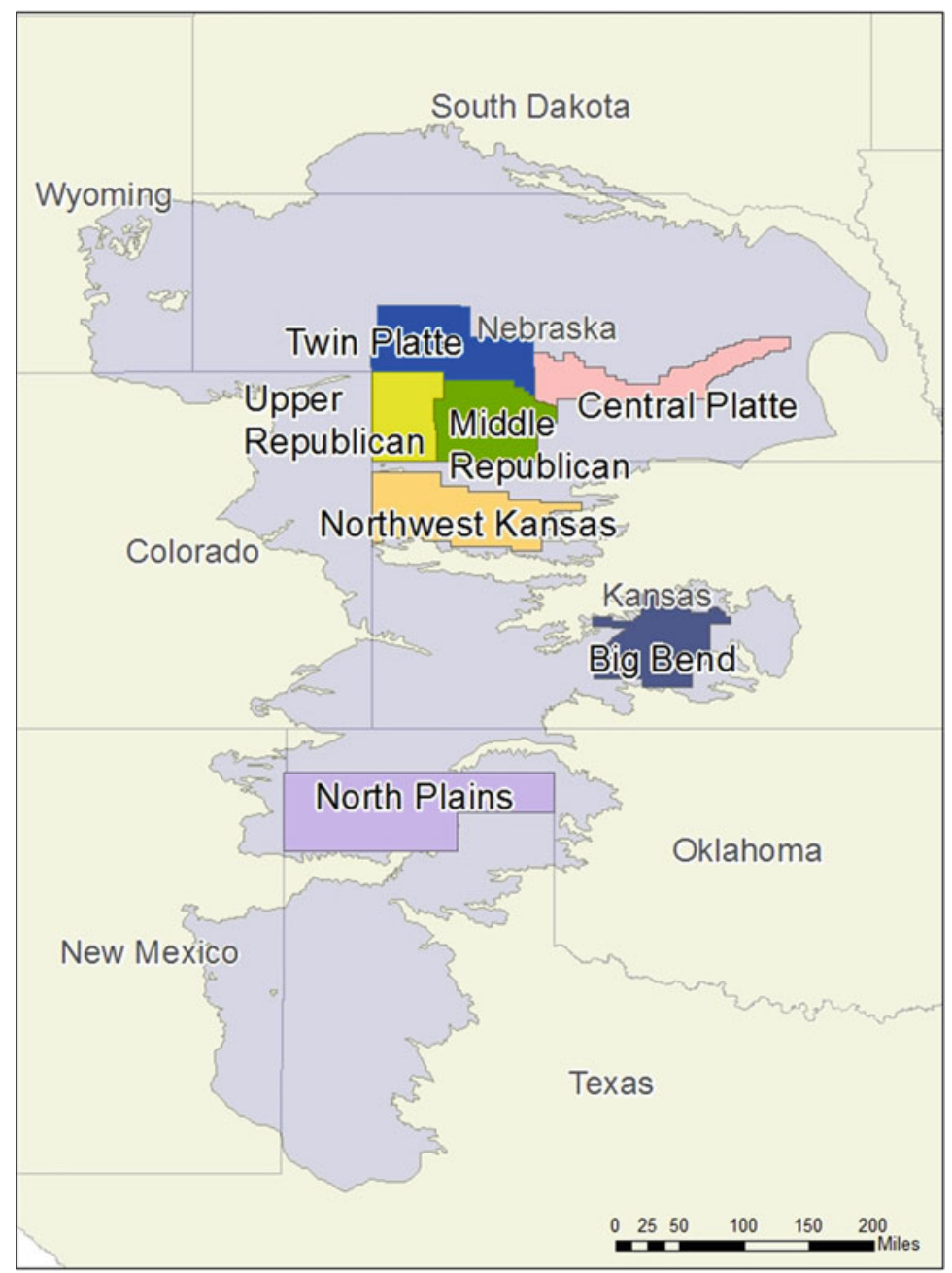

Fig. 22.2 High Plains Aquifer region, with key administrative areas in Kansas, Nebraska, and Texas

had attempted to increase their water use illegally through bypassing their well flow meters.

Note that even without metering of groundwater use, it is possible to estimate groundwater use, and depending on the situation, imperfect monitoring may be sufficient for management. For example, some natural resources districts in Nebraska quantify and enforce the right to irrigate a certain area of land, but do not meter water use (e.g. the Twin Platte and Central Platte NRDs). If crop water demands on a per-area basis are similar, then the estimation error from not metering may be small. Thus, depending on the goals of groundwater management, it may be 
preferable to avoid the potential difficulties associated with metering. However, there is still a need to enforce limits on the irrigated areas for such systems to succeed.

\subsubsection{Transferable Schemes for Groundwater Pumping Rights}

Policies that seek to reallocate groundwater pumping rights must deal with a number of issues. While some of these are well-known from markets for surface water rights (Chong and Sunding 2006; Saliba 1987; Young 1986), others are specific to groundwater pumping. Groundwater pumping leads to several kinds of spatial and intertemporal externalities (Brozović et al. 2010; Kuwayama and Brozović 2013). Indeed, groundwater management schemes that reallocate water between alternate pumping locations are often explicitly designed to change the distribution and magnitude of pumping externalities. Reallocation may be designed to minimize unwanted impacts on third parties or to encourage trades that reduce the magnitude of externalities (Palazzo and Brozović 2014; Brozović and Young 2014).

Externalities arising from groundwater pumping depend on local hydrologic properties and are spatial and intertemporal (Brozović et al. 2010). In principle groundwater pumping produces well interference and induces drawdown in adjacent wells. However, to date interference between adjacent wells with different ownership has not obviously restricted groundwater trading in the High Plains region. One possible explanation is that existing well spacing regulations are enough to prevent significant well interference between adjacent wells. Because trading of the right to pump groundwater changes the location of pumping but does not involve the physical transfer of water above ground, in general no water conveyance system is needed. Note that this is different to most surface water markets, where the need for water conveyance may be a major limitation to trading. Moreover, in groundwater management areas where there are already binding restrictions on groundwater use, water users that are looking to purchase additional pumping rights often have excess pumping capacity and may be able to use any permits they purchase without needing any further capital investment.

Existing groundwater permit trading schemes typically use applied water, rather than consumptive water use, as the unit of trade. Again this is in contrast to surface water markets, where it is common for only consumptive water use to be tradable. The main reason for the difference is likely pragmatic. Well metering quantifies applied water rather than consumptive use and represents a unit of transfer that is politically acceptable to water user groups. Moreover, in many cases both buyers and sellers of groundwater use rights have the same irrigation technology (typically centre pivot systems in the High Plains region of the United States). Consequently, differences in consumptive use between buyers and sellers may be negligible. Conversely, in surface water markets where water is moved outside of basins, or between agricultural and urban water users, the need to quantify consumptive use is much greater. 


\subsubsection{Innovations in Groundwater Management: Nebraska}

Management of groundwater in Nebraska is undertaken by Natural Resources Districts (NRDs). The NRDs are operated as local government agencies but may be thought of as large groundwater user associations. The NRDs have a relatively large amount of autonomy, and determine their rules and regulations in consultation at the state level through the Nebraska Department of Natural Resources. As a result, a wide variety of groundwater management institutions have evolved at an NRD level, reflecting local concerns about water use (Fig. 22.2). For example, (NE DNR and MRNRD 2010; NE DNR and TBNRD 2012; NE DNR and URNRD 2010) in the Platte River Basin in Nebraska, groundwater regulation is driven by stream depletion impacting endangered species habit for fish and migratory birds (Fig. 22.2). There is currently no metering of wells in the NRDs within the Platte River Basin. The Twin Platte, Central Platte, and Tri-Basin (Platte River portion) NRDs currently allow transfers of groundwater pumping rights. Each of these NRDs uses certification of irrigated acres to place an upper bound on the land area that can be irrigated. Then, transfers of certified irrigated acreage are allowed. Stream depletion is calculated over a 50-year horizon and, depending on the NRD, transfers may be adjusted if acreage is transferred to a location with higher stream depletion than the original location. There are also additional spatial limits on trading, such as constraints that trades cannot move water upstream (Twin Platte and Central Platte NRDs) or outside of specified zones (Tri-Basin NRD). Note that the use of certified irrigated acres as the unit of transfer corresponds to an imperfect monitoring of groundwater pumping. However, when the primary concern is stream depletion, encouraging trading to move water further from the river is desirable and, over short to medium management timescales, the benefits of this spatial reallocation may outweigh modest increases in total pumping.

Conversely, groundwater regulation in the Republican River Basin of Nebraska has been driven by interstate litigation between Kansas, Nebraska, and Colorado over the allocations of surface water to each state from the Republican River (McKusick 2002; Figure 2). As a result of a long litigation between the states, all wells in the Nebraska portion of the Republican River Basin are metered, with mandatory annual reporting and moratoria on new wells. The Upper Republican NRD completed metering in 1982, and the remaining NRDs completed metering in 2005. There are pumping quotas in place with complex and changing intertemporal carry forward provisions that allow banking of unused rights for future use. Current updates of the integrated management plans for three of the NRDs in the Republican River Basin, the Upper (UR) and Middle (MR) Republican and Tri-Basin (TB) (Republican River portion) NRDs, allow for some trading of groundwater pumping rights.

The Republican River Basin NRDs that allow trading each have slightly different rules that constrain trading. For example, in the Upper Republican NRD, trades must stay within an area equal in size to a township (36 mile or around $90 \mathrm{~km}^{2}$ ). In the Middle Republican NRD, trading is limited to groundwater users within certain distances from streams. In years in which the Middle Republican NRD is concerned 
about meeting its stream depletion targets under the Republican River Compact, trading may be suspended at the discretion of the NRD. In each of the NRDs, there is an adjustment for differences in stream depletion if pumping rights are transferred to a location where stream depletion is greater than the original pumping location. However, if pumping rights are transferred to a location with lower stream depletion than the original location, no adjustment to the rights takes place.

\subsubsection{Innovations in Groundwater Management: Kansas}

Kansas is unusual in having appropriative, rather than correlative, rights for groundwater. This complicates any policy that seeks to reallocate groundwater pumping between users as any transfer must not demonstrably impact any senior rights holders. Thus, it is possible that concerns over well interference might restrict the potential applicability of groundwater trading schemes. Despite this, groundwater trading has been established in two areas of the state. First in the Big Bend Groundwater Management District (GMD) No. 5, the Wet Walnut Creek Intensive Groundwater Use Control Area is metered with pumping allocations, and transfers are allowed, though they have not yet occurred. GMD No. 5 also operates a groundwater bank through which transfers may occur, subject to large conservation offsets and regulatory complexity. One trade has occurred in the bank.

Second, in the Northwest Kansas Groundwater Management District No. 4, a portion of the district (the Sheridan-6 area) was designated a Local Enhanced Management Area (LEMA) in early 2013. This is the first such area in the state. The LEMA is self-regulating, and has chosen to equalize the seniority of its water rights and reduce the total water allocation by $20 \%$ relative to historic use. Trading is allowed and will be on a volumetric basis without adjustment, as the primary concern is aquifer depletion and not stream depletion.

\subsubsection{Innovations in Groundwater Management: Texas}

Although metering is slowly being introduced to groundwater conservation districts in Texas, conveyance is an impediment to trading in Texas. Under current groundwater law, trading is allowed but the buyer is expected to pump the water at the location of purchase, on the seller's land. Portions of land overlying the Edwards Aquifer (not a part of the High Plains Aquifer) are an exception to this rule, where trading is allowed to change the location of pumping as it is assumed that the area encompassing all potential transfers is small enough that impacts on third parties will not be altered significantly by transfers. The Edwards Aquifer Authority in Texas has implemented well permitting and metering programs and allows transfers of the right to pump up to 1 acre-foot/acre of certified irrigated land (EAA 2012). Both permanent transfer and lease markets exist. 


\subsection{From Command and Control to Markets: Examples from Chile}

The case of Chile is illustrative of a transition from command and control to market based groundwater management policy, where economic incentives play a significant role in allocation of water use rights.

\subsubsection{Legal and Institutional Framework (an Historical Perspective and Recent Evolution)}

The first Chilean text to regulate the use of water is an 1819 Executive Decree which defined the dimensions of an irrigation water use right and responsibility for water intakes. The 1855 Civil Code was the first legal instrument to define that "the rivers and all waters running within natural channels are national goods of public use." In addition, it establishes that access to water is obtained by means of wateruse rights (WUR) "granted by the competent authority." The concept of WUR was further developed in the 1930 Water Code proposal and 1951 Water Code. The latter code defines WUR as follows: "A water use right is an actual right that falls on publicly owned waters which consists in the use, possession and disposal of such waters fulfilling the requirements and in accordance with the rules prescribed herein" (Hearne and Donoso 2005). The 1967 Water Code, implemented in a more centralized political context, reinforces the concept of water as being within the public domain and changed the legal nature of WUR, stressing that these were administrative rights where the State grants the use of the waters, subject to public regulation. These WUR could expire, and the process of water reallocation was to be based on regional water-use plans executed by means of studies that determined the rate of rational and beneficial use (Hearne and Donoso 2005).

The Water Code of 1981 (WC 1981) maintained water as "national goods of public use," but granted permanent, transferable WUR to individuals so as to reach an efficient allocation of the resource through market transactions of WUR. The holder of the WUR is the owner of the right in perpetuity, ownership that is protected constitutionally. However, it is important to note that granted WUR do not constitute a transfer of ownership of the water. The WC 1981 allowed for freedom in the use of water to which an agent has WUR; thus, WUR are not sector specific and can be transferred between sectors as well as within economic sectors. Similarly, the WC 1981 abolishes the water use preferential lists, present in the Water Codes of 1951 and 1967. Additionally, WUR do not expire and do not consider a "use it or lose it" clause.

The WC 1981 specifies consumptive and non-consumptive WUR for both surface and groundwater. Non-consumptive use rights allow the owner to divert water with the obligation to return the same water unaltered to its original source. Consumptive use rights do not require that the water be returned once it has been used. Consumptive and non-consumptive WUR are, by law, specified as a volume per unit of time. In addition, consumptive and non-consumptive rights can be 
exercised in a permanent or contingent manner and in a continuous, discontinuous or alternating mode. Permanent use rights are rights specified as a volume per unit of time, unless there is water scarcity in which these WUR are recognized as shares of water flows. Contingent rights are specified as a volume per unit of time and only authorize the user to extract water once permanent rights have extracted their rights. Continuous rights are those use rights that allow users to extract water continually over time. On the other hand, discontinuous rights are those that only permit water to be extracted at given periods. Finally, alternating rights are those in which water extraction is distributed among two or more persons.

Groundwater in Chile is regulated in Book I, Title VI of the WC 1981 in Articles 58-68. In addition, groundwater is administratively regulated by Resolution No. 425 of the Dirección General de Aguas (DGA - General Water Directory) approved in 2008. Article 58 establishes that any person can explore in order to find groundwater on their property. Exploration on public property requires an authorization by the DGA; should two or more petitions for exploration be presented for the same geographic area, the DGA will define who receives the exploration right based on an auction. If groundwater is found, the user can petition the DGA for a new groundwater use right. The groundwater use right petition must meet the following requirements:

(a) Identification of the aquifer from which the water is to be extracted;

(b) Definition of the quantity of water to be extracted, expressed in liters per second;

(c) Yield and depth of the extraction well;

(d) Specification of the water extraction points and the method of extraction; and

(e) Definition of whether the right is permanent or contingent, continuous, discontinuous or alternating.

The administrative procedure requires that this WUR petition be published in the Diario Oficial, in a daily Santiago newspaper, and in a regional newspaper, where applicable. Previous to the WC 1981 reform of 2005, the DGA could not refuse to grant new water rights without infringing a constitutional guarantee, provided there was technical evidence of the availability of water resources and that the new use would not harm existent rights holders. ${ }^{3}$ At present, if the petition is found to be for speculative reasons the DGA can refuse to grant the solicited WUR. If there is competition for solicited water rights, they are to be allocated through an auction with an award to the highest bidder. This allocation rule between competing WUR petitioners allows water to be allocated to its highest use value.

The Law $\mathrm{N}^{\mathrm{o}} .20,017$ of 2005 amended the procedure to grant new WUR of the WC 1981 and introduced a non-use tariff (patente de no-uso). Due to the difficulties of monitoring the effective use of all WUR, the non-use tariff is applied to all

\footnotetext{
${ }^{3}$ But, the DGA can declare certain aquifers to be fully exploited and refuse to grant new groundwater use rights.
} 
consumptive permanent groundwater WUR that do not count with water intake infrastructure, and to all non-consumptive WUR that do not have water intake and return infrastructure (Law $\mathrm{N}^{\mathrm{o}}$. 20,017 of 2005, art. 129 bis 4-6).

Groundwater resources can be classified as: free, under restriction, and under prohibition. A groundwater resource classified as free implies that new WUR can be granted to petitioners. Groundwater declared under restriction ${ }^{4}$ only allows provisional WUR to be granted; meanwhile, if it is under prohibition, ${ }^{5}$ no new WUR can be granted. ${ }^{6}$ In Chile, the possibility of limiting withdrawals has been contemplated since 1983 (Res DGA 207 of 1983). However, this resolution does not indicate how these restricted groundwater resources were to be managed. DGA Res 186, which establishes that groundwater user communities (GUC) will manage restricted groundwater resources, clarifies this in 1996; additionally, DGA Res 186 establishes that all restricted groundwater resources must have a GUC. At present Res 341 of 2005, Article 63 of the WC 1981, and Article 39 of Resolution 425 of the DGA establishes that GUC are responsible for the management of groundwater resources and of water extractions.

Approximately $70 \%$ of Chilean territory presents no restrictions for groundwater exploitation. There are at least 50 aquifers with a declaration of restriction, all located from the Region of Arica and Parinacota to O'Higgins (Fig. 22.3). There are only two aquifers under prohibition: the first is the aquifer of San José de Azapa in the Region of Arica and Parinacota and the second is the aquifer of Copiapó in the Atacama Region. Even though there could be over 50 GUC, only two GUC exist at present in Chile; one manages groundwater in the restricted aquifer of Copiapó Province and the second one can be found in the Yali sector of the Melipilla Province of the Metropolitan Region.

\subsubsection{Economic Mechanisms/Instruments in Place}

The WC 1981 established that WUR are transferable in order to facilitate WUR markets as an allocation mechanism. Although private water use rights existed in Chile prior to 1981, the previous water codes restricted the creation and operation of efficient water markets. The framers of the 1981 Water Code sought to achieve the efficiencies of market reallocation of water, "the objective of the governmental

\footnotetext{
${ }^{4}$ The DGA can declare an aquifer under restriction if there is a risk of negative impacts of new WUR on existing WURs.

${ }^{5}$ The DGA can declare an aquifer under prohibition if there is clear evidence of a risk of resource depletion due to over-extraction.

${ }^{6}$ The DGA has the authority to provisionally grant groundwater use rights in those areas that have been declared under restriction. The effects of these provisional WUR on other groundwater use rights holders are studied. Should negative impacts be identified in these areas, these provisional WUR are anulled by the DGA; i.e. groundwater may no longer be extracted with these WUR. However, if no effects are identified after 5 years of water extraction, these provisional WUR can become definite WUR.
} 


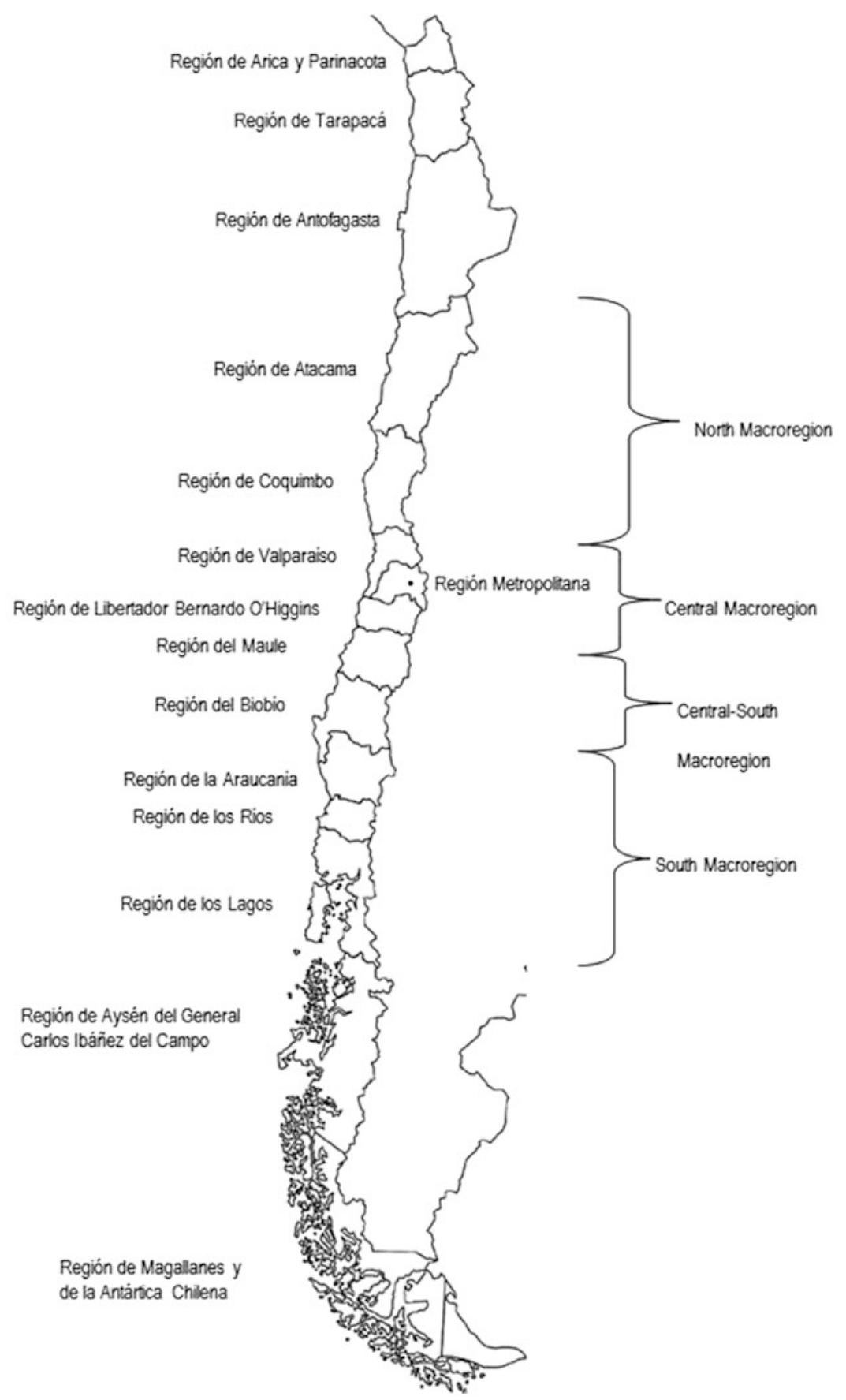

Fig. 22.3 Map of Chile showing different regions 


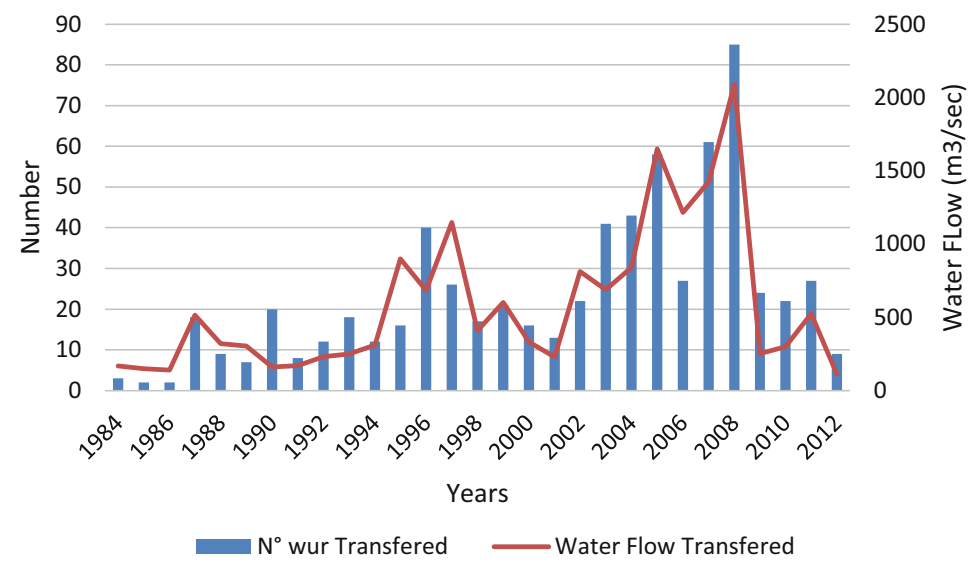

Fig. 22.4 Water flow and number of WUR traded in the Copiapó Aquifer (CNR 2012)

action in this field was to create solid WUR in order to facilitate the proper operation of the market as an allocation mechanism" (Buchi 1993, pp. 85-87). Thus the WC 1981 was designed to protect traditional and customary WUR and to foster economically beneficial reallocation through market transfers (Bauer 2004; Buchi 1993; Hearne and Donoso 2005).

Although market reallocation of water has not been common throughout most of Chile, the existence of water markets has been documented. As Donoso (2012) concludes, studies have shown active trading for WUR in the Copiapó aquifer where water is scarce with a high economic value, especially for the mining sector and the high valued agricultural export sector (CNR 2012). Inter-sectoral trading has transferred water to growing urban areas in the Elqui Valley (Hearne and Easter 1997) and the upper Mapocho watershed, where water companies and real estate developers are continuously buying water and account for $76 \%$ of the rights traded during the 1993-1999 period (Donoso et al. 2002). Other studies have shown limited trading in the Bío Bío, Aconcagua, and Cachapoal Valleys (Bauer 1998; Hadjigeorgalis and Riquelme 2002).

A key conclusion of these studies is that water markets are driven by demand from relatively high-valued water uses, and facilitated by low transactions costs in those aquifers that the DGA has declared as restricted or protected and where there are GUCs present that assist in the transfer of water. For example as Fig. 22.4 shows, in the Copiapó basin, the volume of water and number of WUR traded began to increase as of 1994, when the DGA declared the aquifer under protection (CNR 2012). There was a second increase as of 2002 when the DGA maintained the prohibition for Sectors 1-4 and declared restrictions for Sectors 5 and 6. This resolution reinforced the signal to water users that new WUR were not available for the Copiapó aquifer and, thus new water demands must be satisfied through the market for WUR.

In the absence of these conditions, trading has been rare and water markets have not become institutionalized in most aquifers. It should be noted that during the 
2000s, the market was more active than in the previous two decades, that is in the 1980s and 1990s (Donoso 2012).

\subsubsection{Issues and Problems}

The WC 1981 did not pay much attention to the sustainable management of groundwater because at that time groundwater extraction was marginal during the early 1980s. Recognizing the need to improve groundwater management regulation due to increased groundwater pumping, the 2005 amendment of the WC 1981 introduced procedures to reach a sustainable management of underground water resources. The main provisions are: (a) extraction restrictions when third parties are affected; (b) authorization for the DGA to impose the installation of extraction measurement equipment in order to monitor extractions effectively; (c) the establishment of areas subject to extraction prohibitions and restrictions; and (d) the need to consider the interaction between surface water and groundwater when analyzing petitions for new surface or groundwater WUR.

However, a World Bank study (2011) concluded that there exist various problems associated with groundwater management. A major concern is the general lack of information about groundwater and insufficient knowledge about its dynamics, in particular its interaction with surface waters. There are significant gaps in the registry of wells, extraction and quality measurements, recharge balances, and identification of pollution sources. In general, information systems are not linked to the measurement and monitoring of aquifers to estimate groundwater withdrawals. An effective information system is a prerequisite to be able to control and sustainably manage an aquifer.

The sustainability of northern aquifers is compromised due to the over-provision of WUR related to the practice of allocating WUR based on foreseeable use. The foreseeable use considers the probable effective water extraction of different sectors when analyzing whether there is sufficient water to grant new WUR. For example, an agricultural WUR does not extract water in winter months, whereas a mining WUR extracts water all year round. In this case, the authority would consider a lower pressure on water resources of an agricultural WUR with respect to the pressure of a mining WUR. This practice commits the mistake of not considering the transferable nature of WUR. Thus, when water scarcity increases and inter-sectoral WUR transactions increase, water resources will be overexploited and unsustainable. Additionally, the over-provision of WUR gave rise to increased water conflicts as WUR are transferred to users with a more intensive water use, such as from agriculture to mining in the northern basins.

An additional challenge for a sustainable groundwater management is the fact that at present ground and surface waters are managed independently despite their recognized interrelations even though the 2005 reform of the WC 1981 establishes that surface and groundwater must be jointly managed. This implies that at present there is no conjunctive management of surface and groundwater, which has proven to be an effective adaptation mechanism for climate change. 
There are, in general, no GUCs that manage groundwater user rights; the only exception is in some sections of the over-exploited Copiapo aquifer. There should exist a GUC at least for all aquifers that have a restriction or prohibition declaration by the DGA. The fact that users have not yet organized themselves in GUCs to take over the management of groundwater reflects the lack of understanding of a large proportion of users of the long term effects that uncontrolled exploitation of aquifers may cause. In the absence of GUCs, the WC 1981 establishes that the DGA is responsible for controlling and monitoring groundwater withdrawals. Evidence has shown that the DGA does not have the necessary resources (human, technical, and financial) to monitor all groundwater extractions.

There is an incentive for the adoption of water saving technologies by farmers (Law No. 18,450). This program subsidizes small scale, private irrigation investments. It has supported much of the installation of drip irrigation systems in the dry north and spray systems in the humid south. However, there has been no assessment of the impacts of this incentive instrument on groundwater recharge and sustainability. Hence, it is essential to strengthen the coordination between sectoral policies and water management policies.

\subsection{Conclusions}

One of the lessons learnt from the three case studies is that policies implemented in practice often combine instruments which text books often present as competing options. In Chile, France and the High Plain case studies, policy makers and local managers are actually trying to combine (i) instruments which provide economic incentives and allow for reallocating water with (ii) the development of water user associations and, to some extent, (iii) the formalization of water (use) rights. There is nothing in reality that looks like a pure "market" approach.

Another key lesson is that monitoring and control remains an issue in the three very different contexts, even where full property rights have been established for decades. It is also interesting to note that solutions implemented to solve information problems are somewhat the same in the different countries - all assume that perfect information on water abstraction (e.g. metering) is not a prerequisite and that management can work with less precise information such as a measurement of irrigated area for instance.

A third lesson is that economic instruments enter the management tool box only when water scarcity becomes a real problem or, to use Randall's terminology, when the water economy matures. The High Plain case study shows that different "maturity" levels may co-exist in the same State. Put differently, this implies that the choice of economic instruments that can be used in each specific situation is far from being fully determined by the national legal, institutional, societal and economic framework. Therefore there is probably plenty of room for manoeuvre for local stakeholders to explore the potential for innovative approaches.

Table 22.2 synthesizes the main characteristics of groundwater management in the three case studies. It highlights that incentive-based instruments are framed 
Table 22.2 Comparison of groundwater management in the three case studies

\begin{tabular}{|c|c|c|c|}
\hline & Chile & France & USA - high plains aquifer \\
\hline $\begin{array}{l}\text { Level of } \\
\text { aquifer } \\
\text { regulation }\end{array}$ & $\begin{array}{l}\text { A national policy locally } \\
\text { translated }\end{array}$ & $\begin{array}{l}\text { A national policy } \\
\text { locally translated }\end{array}$ & $\begin{array}{l}\text { No federal policy } \\
\text { regulation. May be some } \\
\text { state oversight. } \\
\text { Groundwater regulation at } \\
\text { local level, which can } \\
\text { differ from one State to } \\
\text { another }\end{array}$ \\
\hline $\begin{array}{l}\text { Groundwater } \\
\text { areas }\end{array}$ & $\begin{array}{l}\text { Free ( } 70 \% \text { of aquifers), } \\
\text { under restriction }(\sim 50 \\
\text { aquifers), under } \\
\text { prohibition ( } 2 \text { aquifers) }\end{array}$ & $\begin{array}{l}89 \% \text { of aquifers } \\
\text { reputed in good } \\
\text { status (Vial } \\
\text { et al. 2010) }\end{array}$ & $\begin{array}{l}\text { Most aquifers with no } \\
\text { restrictions, but a growing } \\
\text { number of active } \\
\text { management areas } \\
\text { Three types of problems: } \\
\text { aquifer depletion, } \\
\text { damages to transboundary } \\
\text { surface water resources or } \\
\text { to ecosystems }\end{array}$ \\
\hline Water rights & $\begin{array}{l}\text { Ancient (1855) water-use } \\
\text { rights -WUR- based on } \\
\text { maximal consumptive } \\
\text { levels. Constitutionally } \\
\text { protected. No "use it or } \\
\text { lose it" clause }\end{array}$ & $\begin{array}{l}\text { No water right. } \\
\text { Only yearly and } \\
\text { revocable water } \\
\text { abstraction } \\
\text { authorizations. } \\
\text { Presently, } \\
\text { definition of an } \\
\text { upper limit to } \\
\text { water abstraction } \\
\text { per groundwater } \\
\text { basin to be shared } \\
\text { between users }\end{array}$ & $\begin{array}{l}\text { Generally no or very few } \\
\text { limits on groundwater use. } \\
\text { In some regions, water } \\
\text { rights defined with or } \\
\text { without water meters. } \\
\text { Kansas: appropriative } \\
\text { rights; other States: } \\
\text { generally correlative } \\
\text { rights }\end{array}$ \\
\hline $\begin{array}{l}\text { Groundwater } \\
\text { withdrawals' } \\
\text { management }\end{array}$ & $\begin{array}{l}\text { Water markets authorized } \\
\text { since } 1981 \text {. Active only in } \\
\text { scarcity areas, when there } \\
\text { exist high-valued water } \\
\text { uses and low transactions } \\
\text { costs }\end{array}$ & $\begin{array}{l}\text { A fee paid to } \\
\text { Water Agency. } \\
\text { Creation of water } \\
\text { users' associations } \\
\text { charged to share } \\
\text { global water } \\
\text { quota. No water } \\
\text { market }\end{array}$ & $\begin{array}{l}\text { A variety of mechanisms } \\
\text { including no restrictions, } \\
\text { well moratoria, limits on } \\
\text { irrigated acreage, limits } \\
\text { on pumping, water } \\
\text { markets }\end{array}$ \\
\hline $\begin{array}{l}\text { Water users' } \\
\text { associations }\end{array}$ & $\begin{array}{l}\text { Compulsory in scarcity } \\
\text { areas since } 1983\end{array}$ & $\begin{array}{l}\text { Compulsory in } \\
\text { scarcity areas } \\
\text { since } 2014 \\
\end{array}$ & Yes, in some areas \\
\hline Problems & $\begin{array}{l}\text { No conjunctive ground } \\
\text { and surface water } \\
\text { management and more } \\
\text { generally no coordination } \\
\text { between sectoral policies } \\
\text { Lack of information on } \\
\text { groundwater dynamics } \\
\text { Few WUA (2) and lack of } \\
\text { monitoring in other cases } \\
\text { Water markets lead an } \\
\text { unsustainable increase of } \\
\text { water consumption }\end{array}$ & $\begin{array}{l}\text { Levels of water } \\
\text { fees not incentive } \\
\text { Law enforcement } \\
\text { Water allocation } \\
\text { efficiency } \\
\text { A perceived unfair } \\
\text { allocation }\end{array}$ & $\begin{array}{l}\text { Generally there are few } \\
\text { restrictions on } \\
\text { groundwater use } \\
\text { Generally, no conjunctive } \\
\text { ground and surface water } \\
\text { management } \\
\text { Extended litigation is } \\
\text { often a prerequisite for } \\
\text { management changes }\end{array}$ \\
\hline
\end{tabular}


taking into account local contexts, in particular historical, institutional and cultural aspects. Where groundwater was traditionally considered as an open access resource, introducing regulations represents a shift in paradigm and is likely to raise significant opposition. Moreover, the level of involvement of users in the definition of groundwater sharing rules is key to understanding the type of instrument chosen and its efficiency. All these aspects explain the current institutions for groundwater management that have developed in the three case studies: the external imposition of water markets in Chile which do not function as expected, a management mostly based on quantitative sharing in France (with few economic instruments), and nascent market instruments in the High Plains Aquifer of the United States.

To conclude, economic instruments are used to encourage groundwater users to adopt water saving behaviours and then to not overexploit groundwater resources while maximising water efficiency. However, using economic instruments for groundwater management is challenging due to the nature of the resource: it is often complicated to define satisfactorily the level of abstraction that allows a sustainable exploitation; it is also difficult to detect groundwater usage, especially where surface water can also be used. Together, this explains why economic instruments sometimes do not function as anticipated because of incomplete information.

Apart from such difficulties, the three case studies point out two main challenges to be able to control groundwater over-exploitation through economic instruments. First of all is the acceptability challenge. For instance, in France, water markets are nowadays not acceptable mainly for ethical reasons; water taxes can also be rejected, a taxable user finding unfair such an instrument which is seen to unduly increase State receipts. Similarly, over most of the United States, restrictions on groundwater use are currently not acceptable to key user groups. The second challenge is enforcement. An example is given by the Chile case where an enforceable property rights' system combined with an appropriate information level of groundwater availability and demand is still lacking; in France, sanctions applicable in respect of non-registered withdrawals are sometimes not applied. Threats cannot be credible, and then an instrument based on them will not function at all.

Open Access This chapter is distributed under the terms of the Creative Commons AttributionNoncommercial 2.5 License (http://creativecommons.org/licenses/by-nc/2.5/) which permits any noncommercial use, distribution, and reproduction in any medium, provided the original author(s) and source are credited.

The images or other third party material in this chapter are included in the work's Creative Commons license, unless indicated otherwise in the credit line; if such material is not included in the work's Creative Commons license and the respective action is not permitted by statutory regulation, users will need to obtain permission from the license holder to duplicate, adapt or reproduce the material. 


\section{References}

Bauer C (1998) Against the current: privatization, water markets, and the state in Chile. Kluwer, Boston

Bauer C (2004) Siren song: Chilean water law as a model for international reform. Resources for the Future Press, Washington, DC

Brozović N, Young R (2014) Design and implementation of markets for groundwater pumping rights. In: Easter K, Huang Q (eds) Water markets for the 21st century: what have we learned? Springer, Netherlands

Brozović N, Sunding DL, Zilberman D (2010) On the spatial nature of the groundwater pumping externality. Resour Energy Econ 32(2):154-164

Buchi H (1993) La transformación económica de Chile. Del Estatismo a la libertad económica. Norma, Bogota

Casari M, Plott CR (2003) Decentralized management of common property resources: experiments with a centuries-old institution. J Econ Behav Organ 51(2):217-247. doi:10. 1016/S0167-2681(02)00098-7

Castaño S, Sanz D, Gómez-Alday J (2010) Methodology for quantifying groundwater abstractions for agriculture via remote sensing and GIS. Water Resour Manag 24(4):795-814. doi:10.1007/ s11269-009-9473-7

Chong H, Sunding D (2006) Water markets and trading. Annu Rev Environ Resour 31(2):239-264

CNR (2012) Capacitación y Apoyo a Comunidades de Aguas Subterráneas, en el Valle de Copiapó. Report Comisión Nacional de Riego (CNR), Ministerio de Agricultura, Chile

de Stefano L, Lopez-Gunn E (2012) Unauthorized groundwater use: institutional, social and ethical considerations. Water Policy 14(S1):147-160

Dennehy KF, Litke DW, McMahon PB (2002) The High Plains Aquifer, USA: groundwater development and sustainability. Geol Soc Lond Spec Publ 193(1):99-119

Desprats J-F, Rinaudo J-D, Montginoul M (2011) Analyse de la relation entre le type d'urbanisation et la consommation en eau des ménages - Le cas de l'agglomération de Perpignan. BRGM, Orléans

Donoso G (2012) The evolution of water markets in Chile. In: Maetsu J (ed) Water trading and global water scarcity: international perspectives. RFF Press, Washington, DC, pp 111-129

Donoso G, Montero JP, Vicuña S (2002) Análisis de los Mercados de Derechos de Aprovechamiento de Agua en las Cuencas del Maipú y el Sistema Paloma en Chile: Efectos de la Variabilidad de la Oferta Hídrica y de los Costos de Transacción. In: Embid A (ed) El Derecho de Aguas en Ibero América y España: Cambio y Modernización en el Inicio del Tercer Milenio. Civitas, Madrid, pp 109-151

EAA (2012) Edwards aquifer authority rules. http://www.edwardsaquifer.org/files/download/ $2 \mathrm{~b} 4674 \mathrm{cbea} 20 \mathrm{e} 5 \mathrm{~b}$

Figureau A-G, Montginoul M, Rinaudo J-D (2015) Policy instruments for decentralized management of agricultural groundwater abstraction: a participatory evaluation. Ecological Economics 119:147-157, http://dx.doi.org/10.1016/j.ecolecon.2015.08.011

Garin P, Loubier S, Campardon M (2013) Irrigation individuelle - irrigation collective: état des lieux et contraintes. Revue SET 11:86-89

Garrido A, Rey D, Calatrava J (2012) Water trading in Spain. In: De Stefano L, Llamas MR (eds) Water, agriculture and the environment in Spain: can we square the circle? CRC Press, Botín Foundation, London, pp 205-216

Gleeson T, Cardiff M (2013) The return of groundwater quantity: a mega-scale and interdisciplinary "future of hydrogeology"? Hydrogeol J 21(1169-1171). doi:10.1007/s10040-013-0998-8

Gutentag ED, Heimes FJ, Krothe NC, Luckey RR, Weeks JB (1984) Geohydrology of the High Plains aquifer in parts of Colorado, Kansas, Nebraska, New Mexico, Oklahoma, South Dakota, Texas, and Wyoming. US Department of the Interior, Geological Survey, Washington, DC

Hadjigeorgalis E, Riquelme C (2002) Análisis de los Precios de los Derechos de Aprovechamiento de Aguas en el Río Cachapoal. Ciencia e Investigación Agraria 29(2):91-99 
Hathaway D (2011) Transboundary groundwater policy: developing approaches in the Western and Southwestern United States. J Am Water Resour Assoc 47(1):103-113

Hearne R, Donoso G (2005) Water institutional reforms in Chile. Water Policy 7(1):53-69

Hearne R, Easter KW (1997) The economic and financial gains from water markets in Chile. Agric Econ 15:187-199

Konikow LF (2013) Groundwater depletion in the United States (1900-2008). US Department of the Interior, US Geological Survey, Reston, Virginia

Kuwayama Y, Brozović N (2013) The regulation of a spatially heterogeneous externality: tradable groundwater permits to protect streams. J Environ Econ Manag. doi:10.1016/j.jeem.2013.02. 004

Laukaitis AJ (2013) Drought's toll on groundwater is steepest on record. Lincoln J Star. http:// journalstar.com/news/local/drought-s-toll-on-groundwater-is-steepest-on-record/article_8c3d377d7dd1-5d11-bdce-7498476a032f.html. Accessed 9 May

Lenouvel V, Montginoul M (2010) Groundwater Management Instruments in a Conjunctive Use System: assessing the Impact on Farmers' Income Using a Mixed Integer Linear Programming (MILP). Ger J Agric Econ 59(3):158-172

Lenouvel V, Montginoul M, Thoyer S (2011) From a blind truncheon to a one-eyed stick: testing in the lab an optional target-based mechanism adapted to groundwater withdrawals. Paper presented at the 18th annual conference of European Association of Environmental and Resource Economists, Rome, 29 June-2 July 2011

Martin de Santa Olalla F, Brasa Ramos A, Fabeiro Cortés C, Fernández González D, López Córcoles H (1999) Improvement of irrigation management towards the sustainable use of groundwater in Castilla-La Mancha, Spain. Agric Water Manag 40(2-3):195-205. doi:10. 1016/s0378-3774(98)00121-8

Martín de Santa Olalla F, Calera A, Domínguez A (2003) Monitoring irrigation water use by combining Irrigation Advisory Service, and remotely sensed data with a geographic information system. Agric Water Manag 61(2):111-124. doi:10.1016/s0378-3774(02)00169-5

McCarl B, Dillon C, Keplinger K, Williams R (1999) Limiting pumping from the Edwards Aquifer: an economic investigation of proposals, water markets, and spring flow guarantees. Water Resour Res 35(4):1257-1268

McGuire B, Lund K, Densmoe B (2012) Saturated thickness and water in storage in the High Plains Aquifer, 2009, and water- level changes and changes in water in storage in the High Plains Aquifer, 1980 to 1995, 1995 to 2000, 2000 to 2005, and 2005 to 2009. U.S. Geological Survey Scientific Investigations Report 2012-5177, 28 p

McKusick V (2002) State of Kansas v. State of Nebraska and State of Colorado: joint motion of the states for entry of proposed consent judgement and approval and adoption of final settlement stipulation. Supreme Court of the United States, Washington DC

Ménard C (2003) L'approche néo-institutionnelle: des concepts, une méthode, des résultats. Cahiers d'Economie Politique 44:103-118

Montginoul M, Rinaudo J-D (2009) Quels instruments pour gérer les prélèvements individuels en eau souterraine? Le cas du Roussillon. Economie Rurale 310:40-56

Montginoul M, Rinaudo J-D (2011) Controlling households' drilling fever in France: an economic modeling approach. Ecol Econ 71:140-150

Mukherji A, Shah T (2005) Groundwater socio-ecology and governance: a review of institutions and policies in selected countries. Hydrogeol J 13(1):328-345. doi:10.1007/s10040-005-0434-9

NE DNR, MRNRD (2010) Integrated management plan. Nebraska Department of Natural Resources and Middle Republican Natural Resource District, Nebraska

NE DNR, URNRD (2010) Integrated management plan. Nebraska Department of Natural Resources and Upper Republican Natural Resource District, Nebraska

NE DNR, URNRD (2012) Integrated management plan. Nebraska Department of Natural Resources and Tri-Basin Natural Resources District, Nebraska

Palazzo A, Brozović N (2014) The role of groundwater trading in spatial water management. Agric Water Manag 145:50-60. doi:10.1016/j.agwat.2014.03.004 
Rinaudo J-D, Montginoul M, Varanda M, Bento S (2012) Envisioning innovative groundwater regulation policies through scenario workshops in France and Portugal. Irrig Drain 61 (1):65-74

Rinaudo J-D, Montginoul M, Hérivaux C, Figureau A-G (2014) Quels instruments pour une gestion collective des prélèvements agricoles individuels en eau souterraine ? Mise en débat de scénarios avec des acteurs du territoire dans 5 départements français. BRGM/RP-63259-FR, Montpellier, February, p 93

Rosenberg NJ, Epstein DJ, Wang D, Vail L, Srinivasan R, Arnold JG (1999) Possible impacts of global warming on the hydrology of the Ogallala aquifer region. Clim Change 42(4):677-692

Saliba BC (1987) Do water markets "work"? Market transfers and trade-offs in the Southwestern States. Water Resour Res 23(7):1113-1122

Salzman J (2005) Creating markets for ecosystem services: notes from the field. N Y Univ Law Rev 80(6):870-961

Scanlon BR, Faunth CC, Longuevergne L, Reedy RC, Alley WM, McGuire VL, McMahon PB (2012) Groundwater depletion and sustainability of irrigation in the US High Plains and Central Valley. Proc Natl Acad Sci. doi:10.1073/pnas.1200311109

Segerson K (1988) Uncertainty and incentives for nonpoint pollution control. J Environ Econ Manag 15(1):87-98

Shah T (2008) Taming the Anarchy: Groundwater Governance in South Asia. Resources for the Future Press (RFF Press), Washington, p 310

Skurray JH, Roberts EJ, Pannell DJ (2012) Hydrological challenges to groundwater trading: lessons from south-west Western Australia. J Hydrol 412-413(0):256-268. doi:10.1016/j. jhydrol.2011.05.034

Steward DR, Bruss PJ, Yang X, Staggenborg SA, Welch SM, Apley MD (2013) Tapping unsustainable groundwater stores for agricultural production in the High Plains Aquifer of Kansas, projections to 2110. Proc Natl Acad Sci 110(37):E3477-E3486

Strosser P, Montginoul M (2001) Vers des marchés de l'eau en France ? Quelques éléments de réflexion. Annales des Mines, Responsabilité et Environnement 23:13-31

Swierzbinski JE (1994) Guilty until proven innocent-regulation with costly and limited enforcement. J Environ Econ Manag 27(2):127-146

Terrell B, Johnson P, Segarra E (2002) Ogallala aquifer depletion: economic impact on the Texas high plains. Water Policy 4(1):33-46

Thompson CL, Supalla RJ, Martin DL, McMullen BP (2009) Evidence supporting cap and trade as a groundwater policy option for reducing irrigation consumptive use. J Am Water Resour Assoc 45:1508-1518

Van Kirk RW, Naman SW (2008) Relative effects of climate and water use on base-flow trends in the lower Klamath basin. J Am Water Resour Assoc 44(4):1035-1052

Van Vugt M (2009) Averting the tragedy of the commons: using social psychological science to protect the environment. Curr Dir Psychol Sci 18(3):169-173

Vial I, Lalement R, Deronzier G (2010) De l'état des eaux en 2009 aux objectifs 2015. Office national de l'eau et des milieux aquatiques (Onema) Paris

Weitzman ML (1980) The "ratchet principle" and performance incentives. Bell J Econ 11 (1):302-308

Wines M (2013) Wells dry, fertile plains turn to dust. New York Times 19 May

World Bank (2011) Chile: Diagnóstico de la gestión de los recursos hídricos. The World Bank, Washington, DC

Young RA (1986) Why are there so few transactions among water users? Am J Agric Econ 68:1144-1151

Zhang L, Wang J, Huang J, Rozelle S (2008) Development of groundwater markets in China: a glimpse into progress to date. World Dev 36(4):706-726. doi:10.1016/j.worlddev.2007.04.012 